Samfundslederskab i Skandinavien

Årgang 36, Nummer 1, 2021, s. 52-58

https://doi.org/10.22439/sis.v36i1.6168

ISSN: 2596-6200

\title{
Teori som verktyg
}

\author{
Av Karin Brunsson *)
}

\begin{abstract}
Resumé
I en nyutkommen antologi beskrivs sexton teorier och perspektiv som företagsekonomer har använt sig av. Utgångspunkten är att teorier är verktyg, som alla studenter och blivande forskare behöver. Det gäller bara att välja. Synsättet tycks inspirerat av allmänna föreställningar om management och chefers beslutsfattande. Men läroböckernas föreskrifter och modeller är sällan tillämpliga i praktiken. Av både chefer och forskare krävs flexibilitet och kreativitet. Verktyg kan begränsa lika mycket som de underlättar. Vad händer om företagsekonomer överger sin devota inställning till teori och i stället ägnar sig åt angelägna organisations- och samhällsproblem?
\end{abstract}

\section{Emneord}

Forretningsmodeller, doughnutøkonomi, bæredygtighed, økologi

") Karin Brunsson er ph.d. og lektor i erhvervsøkonomi ved Uppsala Universitet. 


\section{A. Från bokföring till teori}

När den s.k. universitetsexamenskommittén år 1903 föreslog att bokföring skulle bli ett universitetsämne opponerade man sig från juristhåll. Professor Carl-Axel Reuterskiöld menade att ämnet varken var akademiskt eller tillräckligt praktiskt. I förlängningen skulle förslaget kunna leda till att alla möjliga slags kurser kom att förläggas till universitetet:

Då bokföringskunskap icke skulle blifva föremål för vetenskaplig behandling vid universitetet; [...] då det i öfvrigt på intet sätt sammanhänger med universitetets allmänna uppgifter och det icke kan anses lämpligt eller görligt att vid universitetet eller med dess medel och i dess lärosalar anordna alla möjliga för det praktiska lifvet nyttiga "undervisningskurser" [...] så afstyrker jag på det kraftigaste komiterades förslag (återgivet från Engwall, 1995, 10).

Detta var länge sen. Ämnet har utvecklats, och företagsekonomi är mycket mer än bokföring. Det handlar inte bara om företag utan om alla slags organisationer. Inte heller är det enbart fråga om ekonomi i strikt bemärkelse: vitt skilda frågor tilldrar sig företagsekonomers intresse (exempelvis belöningssystem, riskbedömningar, etik, hållbarhet, börsindex, kvinnligt entreprenörskap och managementkonsulter). Men fortfarande är professor Reuterskiölds fråga aktuell.

Vad är företagsekonomi för slags ämne? Var finns ämnets kärna? Vad studenter med betyg i företagsekonomi måste kunna är inte självklart: Handlar det om att förstå sig på sambandet mellan företagens balans- och resultaträkningar, kunna reda ut skillnaden mellan effektivitet och produktivitet, känna till marknadsföringens fyra (eller sju) p:n, resultatet av Hawthornestudierna eller innebörden av instrumentell rationalitet? Vad menas - egentligen - med företagsekonomisk kunskap?

De första svenska professorerna i ämnet hade grundlig praktisk erfarenhet. Samtidigt som de undervisade fungerade de som rådgivare åt företag och lagstiftare, uppenbarligen utan att se något motsatsförhållande mellan rollen som forskare och rollen som konsult (Carlson, 1989). Omfattande näringslivskontakter kunde till och med leda till att de - som professorn och "företagsdoktorn" Ulf af Trolle - övertog ledningen av företag i kris (Engström, 1995).

Med tiden har dock även synen på företagsekonomi som ett praktiskt inriktat ämne ändrats. Numera betraktas forskning som artskild från (och möjligen en aning finare än) konsultverksamhet. Forskare varnas för att uppträda som konsulter (Alvehus, 2020). I stället har teori blivit ett honnörsord och något som akademiskt utbildade företagsekonomer inte kan undkomma. 


\section{B. Från en managementteori till sexton teorier och perspektiv}

Under många år fanns förhoppningar om en managementteori. Henri Fayol, som utan att själv vara forskare har präglat synen på hur företag bör skötas, definierade teori som en kodifiering av praktiska erfarenheter (Fayol, 1916/2008, 35): ”... en samling principer, regler, metoder och procedurer - erfarenhetsmässigt prövade och kontrollerade".

I mitten av 1950-talet uttryckte Peter Drucker, som enligt tidskriften Business Week (2005) var den som "uppfann" management, förhoppningar om att man inom tjugo år skulle kunna precisera grundläggande principer och erfarenhetsgrundade riktlinjer för management (Drucker, 1954/1986). I Sverige var Eric Rhenman (1965) lika optimistisk: han efterlyste en teori som ökade förståelsen för organisationers sätt att fungera, klargjorde sambanden mellan olika förhållanden och kunde förutse konsekvenserna av skilda handlingsalternativ.

Men det visade sig svårt att relatera en allmän managementteori till management i praktiken - när de skulle testas försvann teorierna i ett töcken ("the theories tend to dissolve when put into testable form"; March och Simon, 1958/1993, 51). I stället borde forskningen inriktas mot speciella aspekter av organisationers verksamhet och beteende - beslut, uppmärksamhet, lärande (March och Olsen, 1975).

Så tänkte man för fyrtiofem år sedan. Författarna till en nyutkommen antologi, Theories and Perspectives in Business Administration (Eriksson-Zetterquist, Hansson och Nilsson, red., 2020) har en annan utgångspunkt. De utgår från att det redan finns en uppsjö av teorier. Forskares problem blir då inte att försöka förstå sig på organisationers gåtfulla beteende; i stället handlar det om att hitta en teori som på ett lämpligt sätt matchar en bestämd forskningsfråga. Boken bygger på ett imponerande samarbete mellan 33 forskare vid tolv svenska universitet och högskolor. Den är utformad som en handbok och är i första hand avsedd för studenter och blivande forskare som ska redovisa sina examensarbeten. I olika kapitel beskrivs översiktligt sexton teorier och perspektiv som företagsekonomer har använt sig av: deras starka och svaga sidor, grundläggande antaganden, terminologi och användning. Läsarna får många förslag på relevant litteratur. Genom att ta med "perspektiv" markerar redaktörerna att de är öppna för en inkluderande attityd till begreppet teori; dock menar de att även perspektiv är teoretiskt grundade (s. 17).

Man kan fundera över hur Fayol, Drucker eller Rhenman hade ställt sig till denna sammanställning (och kanske ler de motsträviga juristerna från förra seklets början ironiskt i sin himmel). Närmare 120 år som akademisk disciplin har inte hjälpt; det saknas fortfarande en svensk företagsekonomisk teori. I stället har forskare förlitat sig till teorier med brittiskt eller nordamerikanskt ursprung hämtade från de nationalekonomiska, sociologiska eller antropologiska ämnena. Två huvudgrupper av teorier urskiljs; en rationalistisk, en annan konstruktivistisk. Teorier som inte passar in i någon 
av dessa grupper kategoriseras som dynamiska, funktionalistiska, kulturella, kritiska - eller så är det fråga om en aktivitet. Studenter och blivande forskare har med andra ord en hel del att välja på.

\section{Från utgångspunkt till resultat}

Svårigheterna att definiera "teori" på något entydigt och allmänt accepterat sätt är omvittnade (t.ex. Conlon, 2002; Brief, 2003). Redaktörerna för Theories and Perspectives in Business Administration har klokt nog avstått från att ytterligare komplicera frågan. Däremot tar de tydlig ställning till fenomenet teori: Teorier är verktyg som ska användas för analytiska ändamål ("analytical tools"). Genom att använda en viss teori får forskare ett speciellt förhållningssätt till sin forskningsfråga. Ett pedagogiskt exempel från spelmarknaden visar hur olika frågor aktualiseras beroende på vilken teori som tillämpas.

Inställningen innehåller en underförstådd jämförelse med management, ett viktigt ämne i företagsekonomisk utbildning. Liksom chefer i organisationer förutsätts behöva speciella verktyg för att fatta beslut, styra och effektivisera organisationers verksamhet (Holmblad Brunsson, 2014), förutsätts forskare behöva stöd av teorier. Teorier blir en utgångspunkt som kategoriserar forskare och forskningsinriktning.

Att management i praktiken skiljer sig avsevärt från läroböckernas antaganden och modeller har varit känt ända sedan Sune Carlson (1951/1991) för sjuttio år sedan publicerade sin studie av verkställande direktörers arbete. Under årens lopp har forskare gång på gång visat hur chefer i praktiken tvingas hantera besvärliga medarbetare, oväntade tekniska problem eller störningar i omvärlden. Forskarna har önskat bättre ordning och reda, långsiktighet och mer målmedveten styrning (Holmblad Brunsson, 2007). Samtidigt bidrar förmodligen just kraven på flexibilitet och kreativa problemlösningar till att göra management till en attraktiv verksamhet. Det krävs inlevelseoch improvisationsförmåga för att vara chef - samma egenskaper som studenter och forskare också behöver.

I båda fallen är språk och redovisning oundgängliga verktyg. Språket bidrar med kategorier, förenklingar och hierarki och är i sig "teoretiskt". Kategorier möjliggör kommunikation och ger förutsättningar för gemenskap och samhälle. "Utan kategorier förvirras både tanke och handling”, skrev geografen Gunnar Olsson (1990).

I kategorier finns föreställningar om samband. Vissa är så väl etablerade att de betraktas som självklara och traderas över generationsgränserna. Att förmedla insikter om hur saker och ting och 
olika slags händelser hänger ihop utgör en självklar, fundamental och nödvändig del av uppfostran och utbildning (Berger och Luckmann, 1966).

Språk och erfarenheter både möjliggör och begränsar. Händelser eller företeelser som inte passar in någon befintlig tankemodell blir lätt förbisedda (och måste ibland tas om hand av någon alternativ uttrycksform, som kroppsspråk, konst eller musik). Även en del vedertagna sanningar mår bra av ifrågasättas (Latour, 1987). Frågan är därför om metaforen "verktyg" förmedlar en alltför instrumentell syn på forskning. Genom att redan i början av ett forskningsprojekt ansluta sig till någon av teorierna $\mathrm{i}$ boken Theories and Perspectives in Business Administration representerar inskränker studenter och blivande forskare medvetet och kanske onödigtvis sina möjligheter att självständigt utveckla sin syn på samhället. Sannolikheten för upptäckter och oväntade insikter minskar.

I förlängningen finns risken att teorier reifieras (om detta inte redan har hänt) och att själva forskningsuppdraget omdefinieras. Då blir forskarna benägna att låsa in sig i bestämda "fält". I värsta fall ser de som sin främsta uppgift att lämna ett bidrag till litteraturen ("add to the literature") - inte till samhället (Brunsson, 2020).

"Det är aldrig för sent att ge upp", hävdar ståuppkomikern Ronny Eriksson. Ambitionen att ordet "teori" ska finnas med i varje examensarbete och forskningsrapport som publiceras vid en företagsekonomisk institution kan vara en missriktad ambition. Möjligen bottnar den i ett upplevt behov av att bevisa att företagsekonomi har en berättigad plats vid universiteten - som om kritiken mot bokföringskurserna fortfarande var aktuell (jfr Engwall, 2020).

Vad händer om företagsekonomer överger tron på att de behöver teori i alla lägen och i stället förankrar sina studier i ett angeläget samhällsproblem? Det behöver inte göra dem mindre kreativa. Forskare är inte ensamma om att kunna abstrahera, generalisera och se samband mellan olika företeelser i samhället. Länge var universiteten tvärtom bastioner för dogmatism och konservativa förhållningssätt (Ellegren, 2019). Nya idéer inom företagsekonomin har inte bara kommit från forskare, utan har hämtats från praktiskt verksamma yrkesutövare, inklusive managementkonsulter.

Inte heller behöver en mer respektlös inställning till teori betyda att ämnet företagsekonomi blir mindre akademiskt. Även om de inte lyckas utveckla någon stor företagsekonomisk teori à la Drucker kan företagsekonomer utveckla mer avgränsade, lagom stora teorier ("middle-range theories"; Merton, 1967). Då blir examensarbetet - liksom forskning och management i praktiken en skapande verksamhet, som handlar om att formulera teorier (Holmblad Brunsson, 2001; 
Swedberg, 2014). Teori blir ett resultat, inte en utgångspunkt. I bästa fall klargörs till sist frågan om vad som menas med företagsekonomisk kunskap.

\section{Referenser}

Alvehus, J. (2020). Formulating Research Problems, translated by Rikard Ehnsiö. Lund. Studentlitteratur.

Berger, P. \& Luckmann, T. (1966). The Social Construction of Reality, A Treatise in the Sociology of Knowledge. London. Penguin Books.

Brief, A. P. (2003). Editor's Comments: AMR - The often misunderstood journal. Academy of Management Review, 28(1), 7-8. https://doi.org/10.5465/amr.2003.26042683

Brunsson, K. (2020). Aldrig mätt. Axess, nr. 6, 20-21.

Business Week (2005). The Man Who Invented Management. November 28, 96-106.

Carlson, S. (1951/1991). Executive Behavior, reprinted with contributions by Henry Mintzberg and Rosemary Stewart. Uppsala. Acta Universitatis Upsaliensis, Studia Oeconomiae Negotiorum 32.

Carlson, S. (1989). Tidigare svensk företagsekonomi. I L. Engwall (red.) Företagsekonomins rötter. Lund. Studentlitteratur.

Conlon, E. (2002). Editor's Comments. Academy of Management Review, 27(4), 489-492.

Drucker, P. F. (1954/1986). The Practice of Management. New York, NY: Harper Collins Publishers Inc.

Ellegren, H. (2019). Hvad nytt och nyttigt, Tillkomsten av landets första lärda sällskap: Kungl. Vetenskaps-Societeten i Uppsala. Uppsala. Acta Universitatis Upsaliensis, Nova Acta Regiæ Societatis Scientiarum Upsaliensis. Ser. V, Vol. 3.https://doi.org/10.7146/politica.v17i4.68765

Engström, C-G. (1995). Ulf af Trolle - distributionsekonomen som blev företagsdoktor. I L. Engwall (red.) Föregångare inom företagsekonomin. Stockholm. SNS förlag.

Engwall, L. (1995). Företagsekonomi som akademiskt ämne i Sverige - från Theatrum Oeconomicum till småländsk handelshögskola. I L. Engwall (red.) Föregångare inom företagsekonomin. Stockholm. SNS Förlag.

Engwall, L. (2020). Fenomenet företagsekonomi. Lund. Studentlitteratur.

Eriksson-Zetterquist, U., Hansson, M. \& Nilsson, F. (2020). Theories and Perspectives in Business Administration. Lund. Studentlitteratur. 
Fayol, H. (1916/2008). Industriell och allmän administration. Stockholm. Santérus förlag.

Holmblad Brunsson, K. (2001). Vad är forskning? Stockholm. Santérus Förlag.

Holmblad Brunsson, K. (2007). The Notion of General Management. Malmö. Liber, Copenhagen Business School Press.

Holmblad Brunsson, K. (2014). Läran om management, Föreställningar i ett organisationssamhälle. Lund. Studentlitteratur.

Latour, B. (1987). Science in Action, How to follow scientists and engineers through society. Milton Keynes. Open University Press.

March, J. G. \& Simon, H. A. (1958/1993). Organizations, Second Edition. Cambridge, MA. Blackwell Publishers.

March, J. G. \& Olsen J. P. (1975). The uncertainty of the past: Organizational learning under ambiguity. European Journal of Political Research, 3, 147-171. https://doi.org/10.1111/j.1475$\underline{6765.1975 . t b 00521 . x}$

Merton, R. K. (1967). On Theoretical Sociology, Five essays, old and new. NewYork, NY. The Free Press. Olsson, G. (1990). Antipasti. Göteborg. Bokförlaget Korpen.

Rhenman, E. (1965). Inledning, Traditionell organisationslära och nyare organisationsteori. I H. Fayol: Industriell och allmän administration. Stockholm: PA Norstedt \& Söners Förlag.

Swedberg, R, (2014). The Art of Social Theory. Princeton, NJ. Princeton University Press. 